\title{
DRAMATURGIA FEMININA NOS TEMPOS DE REPRESSÃO: HILDA HILST
}

\section{WOMEN'S DRAMATURGY IN TIMES OF REPRESSION: HILDA HILST}

Johnny dos Santos Lima'

Alexandra Santos Pinheiro²

RESUMO: Neste artigo, propomos apresentar um breve histórico da escrita feminina no campo da dramaturgia, questionar a baixa produçáo de textos teatrais escritos por mulheres e divulgar a escrita dramatúrgica de Hilda Hilst no período de exceçăo. A pesquisa é de cunho bibliográfico e tem aporte téorico, principalmente, em Vincenzo (1992), Araujo (2017), Pallotini (2008), Ventura (1988) e Foucault (1979). A escrita dramatúrgica de mulheres é pouco estudada no Brasil, visto que encontramos apenas uma autora que levanta a escrita de mulheres nos anos de 1960. Também observamos que escrever teatro no momento em que esta arte é reprimida pela ditadura militar, é, sem dúvida, um ato de resistência. A análise proposta aqui aponta para uma escritora que deixa sobressair múltiplas contradiçōes, sejam elas no âmbito político da época ou pessoais. A dramaturgia de Hilda Hilst representa, assim, o anseio de uma escritora que buscava interagir com um público nem sempre preparado para os seus texto poéticos. Ao tratar de estados políticos de exceçăo, os textos teatrais analisados neste artigo permitem observar os efeitos na vida em sociedade.

Palavras- chaves: dramaturgia; ditadura; Hilda Hilst.

ABSTRACT: In this article, we propose to present a brief history of female writing in the field of dramaturgy, to question the low production of theatrical texts written by women and to divulge Hilda Hilst's dramaturgical writing in the period of exception. The research is bibliographical and has a theoretical contribution, mainly in Vincenzo (1992), Araujo(2017), Pallotini(2008), Ventura(1988) and Foucault(1979).Dramatigical writing by women is understudied in Brazil, since we found only one author who raised the writing of women in the 1960s. We also observed that playwriting at the moment in which this art is repressed by the military dictatorship, is an act of resistance. The analysis proposed here points to a writer who stands out multiple contradictions,

\footnotetext{
1 Mestre na área de Literturas e Práticas Culturais pelo PPG/Letras UFGD. E-mail: johnnydsl@hotmail.com

2 Doutora em Teoria e História Literária pela Unicamp (2007). Professora Associada de Literatura da UFGD. E-mail: alexandrasantospinheiro@gmail.com
} 
whether in the political or personal sphere of that time Hilda Hilst's dramaturgy thus represents the yearning of a writer who sought to interact with an audience not always ready for her poetic text. When dealing with political states of exception, the theatrical texts analyzed in this article allow us to observe the effects on life in society.

Keywords: dramaturgic; dictatorship; Hilda Hilst.

\section{INTRODUÇÃO}

Hilda de Almeida Prado Hilst (1930-2004) nasceu em Jaú (SP), cresceu na capital paulista e, pouco depois de se formar em direito, pela Universidade de Săo Paulo, foi morar em uma chácara em Campinas (SP), que chamou de Casa do Sol. Lá dedicou sua vida à literatura, produzindo poesia, dramaturgia e prosa. A autora viveu e escreveu durante o período de ditadura militar. Iniciou seus escritos com poemas, mas năo obteve o sucesso que esperava. Assim, decidiu escrever teatro porque acreditava que suas palavras estariam mais perto do público. A produçâo teatral da escritora, portanto, está inserida nos anos de 1960, especificadamente de 1967 a 1969, considerados os anos mais tensos do estado de exceçăo brasileiro. Foram oito peças teatrais: A empresa, 0 rato no muro, $O$ visitante, Auto da barca de Camiri, As aves da noite, $\mathrm{O}$ novo sistema, $\mathrm{O}$ verdugo e A morte do patriarca. Nesse mesmo período, é raro encontrarmos escritos teatrais de escritoras no eixo Rio-Sáo Paulo. Tanto que, em nossas pesquisas, conseguimos levantar apenas um livro que apresenta um compilado de autoras mulheres de teatro; entre elas, está Hilda Hilst, premiada em todos os gêneros em que escreveu e homenageada da Feira Literária Internacional de Paraty (FLIP), no ano de 2018.

Em relaçăo à linguagem da escritora, Caio Fernando Abreu defende que ela resulta em um texto fora da "nossa literatura", colocando a autora ao lado de Guimaráes Rosa e Clarice Lispector; que, segundo ele, "só encontraria paralelo em Joyce ou Samuel Beckett" (1982, p.1). De modo geral, o teatro de autoria feminina estabelece uma relaçăo de resistência, de luta contra a repressāo. Elza Cunha de Vincenzo (1992), em seu livro Um teatro da mulher, chama a atençăo na introduçâo para a escrita teatral de autoria de mulheres que aconteceu antes de 1969. Dentre as autoras citadas está Rachel de Queiroz, que, năo obtendo sucesso, preferiu abandonar o gênero. Até entâo, apareciam na dramaturgia teatral mulheres com nomes isolados. A partir de 1969 é que as dramaturgas começam a revelar-se em número significativo, com suas montagens teatrais divulgadas na mídia, quase como um "boom" feminino na dramaturgia.

Vincenzo denomina este momento como nova dramaturgia: "a nova dramaturgia apresentava um tipo de texto e uma proposta diferente em muitos aspectos do teatro que se vinha fazendo com sucesso, em Săo Paulo" (VINCENZO, 1992, p. XIX). Em torno da questăo da estereotipaçăo da mulher, Hilda Hilst esteve à frente de seu tempo. Queria ser protagonista de sua própria história, ser deslumbrante ${ }^{3}$ na funçăo de escritora. Dizia-se em contrapartida poeta, com o termo masculino porque acreditava que os homens detinham mais seriedade para a escrita, falando de temas menos sentimentais que as mulheres. Uma escolha feita mais para impressionar ao pai do que por convicçấo. Era preciso resistir à repressáo. Desta forma, apesar das perseguiçôes, 
a produçăo cultural do país, em todos os campos, teve um aumento significativo, era a arte produzindo sua voz de protesto:

Mas sobrevém o golpe de 64 e o projeto socializante volta a refluir. De imediato, a produçăo cultural năo sofre um estancamento violento. 0 movimento cultural de esquerda, embora confinado, tem ainda relativa possibilidade de fazer circular seu ideário teórico e artístico. E apesar das muitas interferências e açōes da censura, de interdiçóes de obras, de cortes em peças e filmes, os intelectuais conservam alguns meios de luta e protesto, procuram arregimentar-se e defender de todas as formas seu campo de trabalho. De qualquer modo, foi ainda possível continuar produzindo (VINCENZO, 1992, p.10).

É em funçâo da ditadura militar que a arte cresce no país em forma de protesto como o teatro, a música, a literatura, o cinema entre outras. Muitas vezes, indiretamente, porque os artistas que decidiam enfrentar o "novo sistema" sofriam a violência da repressâo. Alguns se exilaram para poder continuar a produçăo, caso de muitos músicos. Hilda Hilst, na impossibilidade de açăo, encontrou na dramaturgia sua forma simbólica de protestar e alertar a populaçáo, marcando os textos também como representaçáo histórica. Além disso, Hilda Hilst revela o temor de sofrer com a violência da repressăo e por isso apostou em uma linguagem simbólica: "Nessa época havia uma repressáo muito grande no país. Por isso, me senti estimulada a passar o meu recado através de analogias, pois nâo podia escrever diretamente; năo queria que me arrancassem as unhas, que me torturassem" (HILST, 2013, p. 108).

A época a que Hilda Hilst se refere é a de 1967 a 1969, conforme reforça Vincenzo: "A perseguiçăo e a tortura tomam proporçōes antes nunca vistas" (VINCENZO, 1992, p.11). Diferentes lutas de classes começam a ser silenciadas: os estudantes, os sindicalistas, os artistas e a sociedade em geral. E é por esse motivo também que os textos teatrais que aparecem a partir de 1969 săo considerados de cunho político:

Político se por político se pode entender também um teatro, que utilizando-se de uma forma próxima do tradicional, ainda assim póe em questăo a condiçăo existencial dos indivíduos que integram determinada sociedade, salientando contundentemente que esses indivíduos săo tais, porque em tais os transformou o conjunto de sistema e o regime político em que vivem (VINCENZO, 1992, p.12).

É notório em quase todas as peças de Hilda Hilst a questăo da condiçăo existencial dos indivíduos e como o sistema conduz sua transformaçăo social. Podemos citar que isso se dá de forma acentuada em quatro das oito peças: As aves da noite, 0 novo sistema, $O$ verdugo e A possessa. Nestes textos, mais do que a violência física, sobressaem as artimanhas discursivas para legitimar a repressáo e os micros processos de subversâo à norma imposta. Também para Hilst acontece uma transformaçáo com o ato da escrita que leva ao outro (o leitor). Araújo lembra ainda que sâo poucas as autoras que conseguem destaque na área teatral, traz alguns nomes, dentre os quais, Hilda Hilst năo aparece:

Dessa forma, a maioria das dramaturgas que recebem publicaçóes de suas obras especialmente antologias - săo as que já foram reconhecidas pela crítica teatral e 
acadêmica, tais como, Maria Adelaide Amaral, Renata Pallottini, Leilah Assumpçăo e Consuelo de Castro (ARAÚJO, 2017, p.2 - grifo nosso).

Ao refletirmos que Hilda Hilst para de escrever teatro em 1969, seria natural que seu nome năo fosse levantado em um estudo realizado após os anos 2000, contudo a citaçăo acima reforça o que a própria Hilda dizia: seus textos, teatrais ou nâo, nâo têm o apreço da crítica, talvez pelo fato de ela ser considerada uma autora de difícil compreensáo. Araújo lembra das autoras que conseguem, a muito custo, publicar seus textos e tê-los reconhecidos pela mídia. Até a data de publicaçáo do artigo de Araújo, ${ }^{4}$ Hilst possuía apenas quatro, ${ }^{5}$ das oito peças publicadas.

O teatro, de forma geral, sofreu, em diferentes momentos históricos, uma intensa repressăo, seja no Brasil ou fora dele. Na América Latina, no contexto de ditadura militar, o teatro foi usado como ferramenta de luta e, por isso, sofria a repressăo. 0 mesmo aconteceu nos Estados Unidos nos anos 50, com a era McCarthy, "essa investida política forçou todo mundo a alterar ou adaptar radicalmente suas vidas e valores" (BOGART, 2011, p.33). O teatro americano estava vetado a qualquer manifestaçâo política ou social, o que levou os artistas, e principalmente os dramaturgos, a explorarem o expressionismo, buscando a subjetividade do "eu interior" para representar o exterior do mundo pós-guerra. Nessa lógica, Hilda Hilst foi muito audaciosa ao trabalhar com a dramaturgia, na tentativa de explicar o mundo, usando novas formas de representaçáo do real. ${ }^{6}$ Encontramos nos textos teatrais vários níveis de representaçáo, sejam eles sociais, políticos, econômicos ou do eu, já que falamos de arte. Ainda que Hilda Hilst escreva sua dramaturgia nos anos de 1967 a 1969, identificamos que o ano marcante na escrita de seus textos é o de 1968, ${ }^{7}$ conhecido como o "ano em que tudo aconteceu". Obviamente que os eventos anteriores no contexto de mundo influenciam. A exemplo da Segunda Guerra Mundial, quando os "Direitos Civis, a organização dos trabalhadores, a educaçăo, a liberdade individual, a violência dos governos, os costumes, as artes, tudo foi duramente questionado" (MEDEIROS, 1999, p.7).

O mundo estava em conflito, os estudantes brasileiros tomaram a frente dos movimentos de luta contra a repressăo, assim como fizeram os jovens franceses de Paris. A luta por direito dos negros e a morte de Martin Luter King balançou os Estados Unidos. A rebeldia norte-americana se mostrava através da arte, principalmente no

4 O artigo foi encontrado nos anais do XII Seminário Nacional Mulher e Literatura e do III Seminário Internacional Mulher e Literatura - Gênero, Identidade e Hibridismo Cultural, do GT Mulher e Literatura da ANPOLL (Associaçâo Nacional de Pós-Graduaçâo em Letras e Linguística), realizados nos dias 9, 10 e 11 de outubro de 2007, na Universidade Estadual de Santa Cruz, Ilhéus/Bahia.

5 A empresa, O rato no muro, O visitante e o Auto da barca de Camiri, publicado em 2000 pela Nankin Editorial. A Editora Globo detinha os direitos da obra de Hilda Hilst, mas só publicou seu teatro completo em 2009.

6 “Num momento de textos comedidos, cronometrados, 'bem pensados', impossível nâo considerar positiva a intensa vontade de libertaçâo do texto hilstiano, passando por cima de todas as convençóes linguísticas e literárias, numa busca obsessiva de outras formas de representaçâo do real" (apud DINIZ, 2013, p. 217).

7 Hilda Hilst escreve quatro de suas oito peças neste ano, das quais três analisamos nesse estudo: 0 Visitante (1968), As aves da noite (1968), O novo sistema (1968). O verdugo é de 1969, foi contemplada com o Prêmio Anchieta e é o texto teatral mais conhecido da autora, por este motivo a trouxemos para a análise. Buscamos dar atençáo a dramaturgia menos estudada da autora, desta forma A Empresa (1967), O rato no muro (1967), O Auto da barca de Camiri (1968) e A morte do patriarca (1969), náo fazem parte do corpus dessa pesquisa. 
cinema, que também começava a aparecer no Brasil. Che Guevara se tornou símbolo da revoluçăo na América Latina, seus ideais eram partilhados pelos estudantes na busca da "liberdade de direito". Marcuse e seus ideais faziam parte do pensamento jovem, tendo três de seus livros entre os mais vendidos do período. Nesse contexto mundial, o Brasil vivia o auge da repressăo, os estudantes estavam diretamente em conflito com os militares, os atos institucionais serviam como controle, os direitos civis e políticos do país foram cassados, as passeatas reuniam a classe artística, os trabalhadores e os estudantes. O teatro de Arena, o show Opiniăo, o teatro Oficina, todos eram censurados; assim como a música. Artistas e políticos tiveram que se exilar do país para nâo sofrerem a represália dos militares. De maneira abrangente, "a arte virou resistência política - era preciso resistir e denunciar" (FIGUEIREDO, 2015, p.11).

Os eventos que antecederam, sucederam e estiveram presentes durante o ano de 1968 ajudam a (re)pensar as representaçôes contidas na arte considerada mais engajada daquele momento: o teatro. E, principalmente, colaboram no entendimento das possíveis representaçôes da dramaturgia de Hilda Hilst, que "năo se limita ao contexto político do Brasil" (OLIVEIRA, 2013, p.56). De muitas formas, no Brasil, a ditadura militar, que durou 21 anos, deixou marcas, e"os palcos tornaram-se verdadeiras trincheiras de resistência e embate na luta contra o regime de exceçáo" (FIGUEIREDO, 2015, p.8).

A arte teatral que se apresentou nesse período é extremamente engajada. Companhias de teatro, como Arena e Oficina, ou grupos teatrais estudantis tinham como lema a luta contra o sistema ditatorial. Os textos teatrais hilstianos fogem ao "padrăo" da época, pois aparecem altamente poéticos, com representaçóes mais voltadas para o existencialismo do ser. Embora diferente, a dramaturgia hilstiana incorpora o discurso da resistência ao estado de exceçấo: "[...] o discurso da classe artística nesse período em tela conjugava, além da representaçăo da cena, também, a dor, a luta, o sofrimento e a resistência contra o arbítrio militar" (FIGUEIREDO, 2015, p.8). Hilda Hilst consegue trazer para cena năo só as dores do mundo, mas também a ideia de um "eu" que sofre e sente-se incapaz diante desse mundo. Um "eu" que viveu de utopias, da repressâo estabelecida por um sistema, levando-nos a questionar Deus/religiâo, o ser Humano, a violência: a "nos lembrar das grandes questóes humanas, nos lembrar de nosso terror e de nossa humanidade" (BOGART, 2011, p.86).

O estado de exceçáo é uma ferramenta específica para a dominaçāo. Na dramaturgia de Hilda Hilst ele pode ser percebido em diferentes esferas: na política, na religiosa e no familiar. Nesta análise, abordamos as peças: As aves da noite, 0 novo sistema, 0 verdugo e 0 visitante.

\section{REPRESSÃO: 0 MEDO QUE NOS LEVA A FAZER COISAS ABSURDAS}

No Brasil do final dos anos 60, do século XX, a repressăo se instaurou de todas as formas possíveis. As ameaças militares se impunham năo só pelos atos institucionais, sobretudo pela presença do "policiamento" militar nas ruas, pela imposiçâo da "ordem", da "moral" e dos "bons costumes". Ressaltamos que o ano de 1968 foi o marco da luta estudantil no país, e também o ano em que Hilda Hilst mais produz sua escrita teatral. Paralelamente à escrita das peças teatrais da escritora, havia os grupos que se manifestavam de maneira mais direta. A classe estudantil foi a que mais esteve envolvida 
em perseguiçóes militares, automaticamente, permaneceram enredados em todo o contexto político: "Os estudantes brasileiros tinham mais petulância do que os seus colegas franceses" (VENTURA, 1988, p.140). Năo por acaso, a dramaturgia de Hilda Hilst apresenta vários personagens "estudantes", que, curiosamente, năo voltará a aparecer em suas obras de ficçăo:

Seu trabalho [de Hilda Hilst], visto em conjunto, dá-nos o retrato de uma situaçáo injusta, de um mundo feito por homens submetidos à força, de um mundo ameaçado pelo poder absoluto e despersonalizante, poder que se defende fazendo emudecer as vozes dos artistas e poetas. Seus heróis rebeldes săo esmagados pela força, seus jovens inquietos sâo calados (PALLOTINI, 2008, p.517 - grifo nosso).

Nesse período de instabilidade dos direitos individuais, falar demais era perigoso, as lideranças estudantis, sindicais e políticas que se mantivessem em oposiçăo ao sistema militar eram intimadas pelo regime. Fazia-se necessário calar a voz do povo. Em $O$ verdugo, por exemplo, o personagem intitulado Homem aparece julgado pelos juízes como um agitador, alguém que "confundiu as gentes" e por isso deveria ser morto, silenciado. Sob este olhar, poderíamos dizer que se trata de um teatro de resistência. É importante lembrar que esta peça foi escrita em 1969, quando já estava instaurado o AI-5, sendo o ano anterior marcado pela prisáo de políticos, artistas e líderes de movimentos. Também é latente a representaçâo do golpe militar de 1964 no diálogo abaixo:

Verdugo (Para os juízes): Eu acho que o homem năo merece, os senhores entendem? Juiz jovem: Năo merece o quê? (Pausa).

Verdugo: A morte. $O$ homem năo merece a morte.

Juiz velho: Mas isso já foi decidido. Ele foi condenado.

Juiz jovem (Para todos): Os senhores viram que fizemos todo o possível.

Noivo: E o impossível, Excelências. Vamos muito bem.

Juiz jovem (Para todos): Ele teve todos os direitos. Fizemos tudo.

Juiz velho (Para todos): Nada lhe foi negado. Entăo... (Pausa).

Verdugo: Mas ninguém ficou satisfeito. A gente toda da vila...

Juiz jovem (Interrompe): Mas năo é a vila que julga o homem. Pra isso nós existimos. Já dissemos, foi tudo dentro da lei (HILST, 2008, p.383).

A contestaçâo dos parâmetros dito "legais" contradita pelos juízes estabelece relaçấo com o Golpe de Estado, uma vez que "todos os direitos" foram concedidos, ironicamente, "foi tudo dentro da lei". Conjuntura que parece se repetir no contexto político atual do Brasil (2016/2017). O Homem é uma ameaça. Mesmo que as pessoas náo vejam tal afirmaçáo, é preciso sanar o "problema" antes que a justiça perca o controle do povo. A repressăo passa por cima dos interesses da "massa" e se restringe ao interesse do dominante, aquele que possui o poder e o controle. Nessa peça, năo temos a presença de um personagem estudante, como em As aves da noite e $O$ novo sistema, todavia existe a do Filho, que representa o jovem com desejo de justiça, que quer lutar contra o sistema e que fará todo o possível para alertar a populaçáo a respeito da manipulaçăo da lei; aqui representada como quem diz o que é certo e o que é errado. Hilda Hilst é formada em Direito, portanto, conhecedora da lei, da justiça. Há aqui, também, uma crítica à 
forma de controle dos que detêm o poder da lei, que nessa ocasiăo também pode ser visto com a Ditadura.

No livro 1968: O ano que nâo terminou (1988), Zuenir Ventura descreve os encontros clandestinos de artistas e estudantes que se uniam na calada da noite para organizarem as manifestaçóes que ocorreriam durante o dia. Hilda Hilst utiliza metáforas que parecem se identificar com a descriçấo de Ventura sobre os jovens brasileiros e seus encontros clandestinos:
Juiz jovem: Ele chamava vocês de coiotes. (Verdugo e filho entreolham-se).
Noivo: $O$ que é isso?
Filha: $O$ que é um coiote?
Juiz jovem: Um animal. Um lobo.
Mulher (Para o filho): E você defende um homem assim?
Filho (Para a mulher, exaltado): Nâo é isso, máe. Ele dizia que os coiotes năo costumam viver eternamente amoitados. Que é preciso sair da moita.
Mulher: E o que é que nós temos com os coiotes?
Juiz velho (Para o filho): Sair da moita para caçar?
Filho (Exaltado): Para que vejam ao menos as nossas caras de coiotes e respeitem a gente. E se nos respeitarem, nós poderemos um dia... (Lentamente) achar o nosso corpo de pássaro e levantar vôo. (Objetivo) Mas primeiro mostrar a cara de coiote.
Mulher (Com desprezo): Pássaro... Coiote... O homem é louco.
Juiz jovem (Aproximando-se do filho): E como é a cara de um coiote?
Filho (Encarando fixamente o juiz jovem com uma expressăo de dureza e ameaça): Uma cara... Assim.
(Batidas fortes na porta) (HILST, 2008, p.395).

Aqui, os coiotes săo como o Filho; já o Verdugo representa a luta dos estudantes no regime militar. Os homens coiotes săo os que lutam em defesa do seu grupo, é a representaçăo do povo que precisa mostrar as garras diante da censura e da repressáo. Revelar as caras de coiotes, levantar voo, uma série de metáforas possíveis de serem aplicadas aos que fizeram história nos anos de 1960: "Como năo podia haver comunicaçâo cara a cara, entâo fiz peças, todas simbólicas, porque eu náo tinha vontade nenhuma de ser presa, nem torturada, nem que me arrancassem as unhas... Entấo, fiz por analogia várias peças em que qualquer pessoa entenderia o que se pretendia dizer numa denúncia" (HILST, 2013, p.130). Hilda Hilst menciona uma ditadura militar específica, a brasileira, todavia, apoia-se também em todo o processo que viveu a América Latina e o mundo. Nesse contexto, ser coiote, ter uma expressâo de dureza e ameaça diante dos "juízes", era sofrer consequências semelhantes à do homem, ou seja, a prisấo e a morte.

Em $O$ novo sistema, a repressāo é representada pela metáfora da disciplina de Física: ${ }^{8}$

8 Talvez, a escolha pela metáfora com a física tenha se dado pelo fato de a autora aventurar-se em experimentos radiofônicos com os mortos e por ter muitos amigos físicos. 
Voz do Escudeiro-mor: Página 17: Todo corpo permanece em seu estado de repouso ou de movimento uniforme em linha reta, (Voz violenta) se năo for obrigado a mudar de estado por forças nele aplicadas. Se năo for obrigado a mudar de estado por forças neles aplicadas. A coletividade entendeu?

Vozes das crianças: He! Ha! (Três vezes).

Voz do Escudeiro-mor: Uma força imprimida é uma açáo exercida sobre um corpo a fim de modificar o seu estado. (Lentamente) A força consiste somente na açăo. (Destaca) Açăo. (Pausa) E tudo isso quer dizer no Novo Sistema.... Tudo isso quer dizer... (HIST, 2008, p.307, grifo nosso).

No fragmento acima, a imagem da repressăo é dada a partir uma ideia do uso das forças sobre a vontade dos corpos, ou seja, a violência, a repressâo. Hilst destaca na rubrica a entonaçăo da voz, isto é, a forma como ela está dita, fazendo uso da palavra "violenta", além de repetir uma oraçăo para reforçar o propósito de poder por meio de um Escudeiro-mor, claramente representando uma conjuntura militar. Essa passagem é do início do texto e sugere que o novo sistema é a Ditadura Militar.

A margem é representada como aqueles que năo entendem o sistema, e, por isso, năo podem ter reaçăo. O Menino, que é o personagem principal da peça, é um poeta, já escreveu contos e poesias, por essa razăo, os pais dizem que ele possui uma sensibilidade: "Năo é um menino que se possa gritar" (HILST, 2008, p.318). Em analogia a este personagem, Hilda Hilst também se representa enquanto escritora, diante de um sistema de controle e repressăo. Este menino, por ter tanta sensibilidade, năo compreende como as pessoas vâo parar penduradas nos postes e tem o olhar demorado para os homens que estăo mortos. Isso preocupa os pais, que podem sofrer o poder do controle diante da curiosidade do filho.

O triângulo de cenário, ao fundo da peça, faz relaçăo com a pirâmide sugerida em As aves da noite. Em um dos documentários sobre Hilda Hilst ${ }^{9}$, Mora Fluentes afirma que a autora teria sonhado com um triângulo ${ }^{10} \mathrm{em}$ volta de um círculo, representado nos textos teatrais como um símbolo emblemático, lembrando a humanidade, o sistema, a religiăo. "O novo sistema", representado na dramaturgia, deixou muitos mortos:

9 Simplesmente, Hilda. Disponível em: 〈https://www.youtube.com/watch?v=monUakZz1Ck\&t=749s>, acesso em 07 de julho de 2017.

10 "Mesmo sendo um dos símbolos geométricos mais simples e fundamentais, o triângulo abrange uma gama de significados. Ele é o símbolo da trindade dos deuses - Santíssima Trindade - nas culturas cristā, hindu, egípcia e babilônica e, por ser formado por três segmentos, o triângulo faz alusăo também às tríades início, meio e fim e corpo, alma e espírito" (SIMBOLOS, 2017, p.1 - grifo do autor). 0 triângulo com a ponta para baixo também representa o feminino, para cima o masculino, segundo a astrologia. De maneira geral, o triângulo dentro do âmbito religioso fará referência à Trindade, na maçonaria seria como a representaçáo de Deus. 
Pai: Claro, muito satisfeito, claro. (O escudeiro 1 começa a desamarrar os pés de um dos homens) Vâo recolher, entăo?

Escudeiro 1: Para colocar os outros.

Pai: Ah, sim. Săo muitos?

Escudeiro 2: Incrível, senhor, incrível. O Escudeiro-mor năo esperava tanto. Ele nos disse que sáo tantos como formigas. (Ri) Aquelas grandes com asas... o senhor sabe.

Pai: É... As asas.

Escudeiro 1: Tempos inquietantes, hein, senhor?

Pai: Bem, se é para melhor, tudo vai bem. É preciso colaborar (HILST, 2008, p.324).

Parece que existe uma combinaçâo de imagens na dramaturgia hilstiana, que ora representa os contextos brasileiros, ora a América Latina e, em certos momentos, os resultados da Guerra. Năo se sabe ao certo de quantos mortos os escudeiros estăo falando, porém, entende-se que sâo muitos, pela comparaçăo que os SSs fazem com as formigas. Podemos ter mais uma referência ao Nazismo, que culminou em milhóes de Judeus assassinados. Outro aspecto que assegura essa aproximaçăo é o fato dos escudeiros sempre compararem sua funçâo com a dos higienistas ${ }^{11}$. Aqui a comparaçăo com a física exige que as pessoas náo se esqueçam das regras impostas pelo novo sistema. Também no período da ditadura brasileira, nem os próprios militares assumiam o estado de exceçấo, era tratada como uma nova forma de governo. A metáfora percorria os discursos dos que detinham o poder naquele tempo.

Ainda no sentido de representar a repressâo de diversas formas e por várias linguagens, o hibridismo hilstiano é apresentado com uma concepçâo poética dentro da dramaturgia:

Menina: Meu pai hoje me mostrou a última poesia do Novo Sistema. É linda. Eu vou te dizer (diz lentamente com muita gravidade):

Nós devemos ser iguais à pedra

Que no grande mar do Novo Sistema.

Mergulha.

Nós devemos ser iguais à pedra

E năo como a cortiça que flutua.

(Pausa).

Você náo se lembra de nada que tenha analogia com esse poema? (HILST, 2008, p.343).

11 Os higienistas surgem por volta do século XIX para cuidar das doenças e controlar as epidemias. O papel dos escudeiros seria o de limpar a cidade, assemelhando-se às ideias de pureza pregadas no regime nazista. 
A Menina apresenta para o Menino a poesia do sistema: "Pedra que afunda no mar". Ela é a pedra, que afunda e permanece no fundo do mar, rígida, dura, sem movimento. Novamente há a relaçăo com o controle. Já o menino é a cortiça, flutua, se move, nâo permanece no mesmo estado, é afetado pelas ondas do mar, năo quer se render ao sistema.

Em Teatro do oprimido e outras poéticas políticas, Augusto Boal (1991) discorre desde a mimèsis representativa no teatro, até as reverberaçōes de opressor e oprimido no contexto contemporâneo. Parcialmente, boa parte de seu trabalho deve-se à própria experiência de Boal à frente do Arena, as perseguiçóes e influências de outros países da América Latina por onde passou durante o exílio no período de Ditadura no Brasil. Boal nos auxilia a (re)pensar como um sistema autoritário é capaz de transformar as personalidades e subverter o sistema, aspecto também apontado por Foucault (1979) em Microfísica do poder. ${ }^{12}$ Quem era oprimido passa a oprimir e vice e versa. É a transformaçăo do ser Humano. Hilda Hilst resgata, em alguns momentos, essa reflexăo conceituada anos depois por Boal:

Filho: Cáo lazarento. (O noivo aproxima-se mais) Porco.

(O noivo esbofeteia o rapaz)

Mulher (Para o noivo): Pare com isso.

Filho (Para o noivo): Só assim mesmo, canalha. Só eu amarrado (HILST, 2008, p.399).

Este trecho de $O$ verdugo exemplifica a facilidade em se transformar em opressor. O Noivo sempre está em conflito com o Filho, contudo, náo faz uso de força física, exceto no momento em que o Filho se encontra amarrado, quer dizer, em desvantagem. Vemos de novo o uso do poder e a modificaçăo da personagem. Já em O novo sistema, essa mudança é mais evidente:

Menina: Eu sei tudo. Você se emocionou com os homens amarrados. Eu já te disse, os olhos devem registrar a cena, rápidos como um relâmpago. É só para provocar uma reaçăo interior automática, eu năo te disse. Automática. Pense nas melhores câmaras fotográficas.

Menino: E você já sabia de tudo isso quando chegou aqui perto de mim?

Menina: Sim. Eu fui avisada. Uma das minhas tarefas é essa, năo permitir que as crianças iguais a você perturbem o trajeto de seus pais anêmicos para a morte.

Menino (Com extrema gravidade): E é isso que você fez comigo até agora. Você simplesmente ganhou tempo?

(Pausa) (Desesperado) Enquanto meus pais... Eu compreendi... Eu compreendi.

12 "[...]no ponto em que o poder encontra o nível dos indivíduos, atinge seus corpos, vem se inserir em seus gestos, suas atitudes, seus discursos, sua aprendizagem, sua vida quotidiana (FOUCAULT, 1979, p. 131). 
Menina: Mas você náo parece contente. E você devia estar contente.

Menino: Por quê?

Menina: Por ter compreendido. A nossa única alegria é o entendimento.

Menino: E tudo será sempre assim? O entendimento sem amor? Sem amor?

Menina: Sempre. (O menino aproxima-se da menina. Num gesto rápido pega o cinto que estava no chăo e o coloca no pescoço da menina) É tolice você fazer isso. Você está me machucando. (Rapidamente) Náo adianta, minha morte năo te salvará do Instituto e nem salvará teus pais da morte. Eles já estâo mortos. Nâo adianta. Pare. Nâo adianta... (HILST, 2008, p.355).

A menina é morta pelo menino. Neste recorte, a crítica de Hilda Hilst parece ser o conhecimento: um saber que mata. Ao se deparar com a verdade, o Menino enlouquece, compreende que o sistema náo perdoa, nem mesmo seus pais. Isso o leva a reagir igual a tudo que ele questionava até entấo. O Menino nâo entendia porque os homens eram colocados no poste, nâo compreendia a metáfora da física, náo assimilava como a violência se estabelecia como soluçáo dentro do sistema. No momento em que vira o agressor, passa a oprimir, existe a transformaçăo das personagens e a hipocrisia humana é evidenciada.

Outra forma de repressăo praticável representada por Hilda Hilst é a sexual:

\author{
Uma flor para um homem, já pensaste? \\ Até a mulher podia duvidar \\ Se serias ou náo, mensageiro amoroso \\ De uma trama (HILST, 2008, p.162).
}

Homem (Levantando-se): Ainda bem que foi Ana e náo fui eu.

Existe uma conotaçăo ambígua no Homem: representa também a bissexualidade. Ele encontra Meia-Verdade no meio da noite, se assusta, convida-o para ir a sua casa, diz que se olharam e riram: "afinal éramos dois homens plantados ali e quietos como dois lobisomens" (HILST, 2008, p.161). Essa ambivalência nos sentidos se justifica no contexto de liberdade sexual que permaneceu durante os anos de 1960/70 surgido pelo movimento Hippie, que tinha como lema: "sexo, drogas e Rock 'nRoll", como aponta Medeiros (1999) no livro: 1968: esquina do mundo. Ainda que essa possibilidade năo apareça em nenhum outro estudo analisado sobre a peça, é possível encontrar coerência na análise de representaçăo, visto o contexto de mundo em que foi escrita e o fato da personagem Meia-Verdade, que é o visitante, aparecer na casa e depois ir embora sem ser notado. Em outro momento, também aparece um jogo de desconfiança ambígua por Maria: 
Maria: E náo achas estranho

Que um homem te convide

À própria casa

Sem te conhecer?

Entregas por acaso

Teu rebanho

A um forasteiro? (HILST, 2008, p.179).

Mesmo que Meia-Verdade pareça encantado com Ana no decorrer do texto, o que podemos perceber é um jogo de autoafirmaçâo da personagem enquanto homem, passível de questionamento diante da época retratada pela peça: o período medieval, em que assumir uma sexualidade diferente năo era uma opçâo. Como dissemos, o estado de exceçấo na obra de Hilda Hilst deve ser entendido como todas as formas que podem aprisionar o homem. Já em 1969, Hilst mostra o poder do capitalismo:

Cidadão 5 (Para os juízes): A gente recebe o dinheiro logo?

Juiz jovem: Assim que o homem morrer.

Verdugo (Desesperado, subindo no patíbulo): O homem é bom, gente. Olhem pra ele.

Cidadão 1: A gente não vê mais a cara.

(Risos) (HILST, 2008, p.421).

A transformaçăo dos cidadăos evidencia o interesse no dinheiro oferecido pelos juízes, o dinheiro é capaz de comprar opiniōes, no entanto, mais do que isso, é visto como um silenciador. Por dinheiro, a populaçăo nâo irá contestar a justiça e tampouco falar sobre o assunto. $O$ dinheiro é a máxima representaçăo do poder no mundo capitalista, é por conta dele que existe tanta corrupçấo do homem, indo além dos interesses políticos. Para calar as dúvidas e modificar os valores pessoais, é preciso barganhar, se apropriar dos discursos coletivos:

Juiz jovem: O homem esteve sempre contra vocês. Qualquer um que póe o povo contra as autoridades está contra vocês.

Verdugo (Para os cidadáos): Mas pensem, pensem... se ofereceram dinheiro...

Juiz jovem: Ofereceram dinheiro para que vocês se animem a nos ajudar.

Juiz velho: Com dinheiro é mais fácil um ajudar o outro (HILST, 2008, p.422). 
O Verdugo é questionado pelos cidadăos que náo entendem o porquê de ele defender o Homem, chegam até a sugerir que existe parentesco entre eles. A justificativa da morte é que o dinheiro ajudará a todos, inclusive a Filha que precisa da quantia para o casamento. Entấo, o homem fala pela primeira vez, pedindo que o matem de maneira rápida. A única forma de acabar com o sofrimento em situaçōes limites é desejar a própria morte. Năo há mais com o que lutar, o povo, que antes era seu semelhante e o apoiava, está contra ele, pedindo que o Verdugo o mate. O verdugo, por sua vez, diz que năo o fará. Em desacordo, o povo avança sobre o homem, contudo o verdugo tenta defendê-lo:

Voz do verdugo (Com intensa comoçăo): Năo. Năo. Eu morro, mas... (Frase: “Entăo morre" - Começam a dar pauladas no homem e no verdugo. Cena de intensa violência. Frases soltas: “Dá uma no olho de cavalo" - "Toma você também, seu porco" - Terminam a chacina. Recuam vagarosamente. Silêncio esticado. Descem do patíbulo. Vê-se o homem e o verdugo lado a lado, mortos)

Juiz velho (Quebrando o silêncio): Nós năo queríamos que fosse assim. (Mulher, filha e noivo se unem amedrontados, num canto. $O$ carcereiro solta o filho e este sobe no patíbulo e olha para o verdugo, estarrecido) (HILST, 2008, p.427).

As agressóes, o pedido de morte do Homem, indicam um ser que se rende ao sistema, representado principalmente pelo assassinato das personagens. A repressăo foi constante para que o Homem abandonasse o seu desejo de luta e se entregasse à vontade dos juízes, como Jesus, que foi negado por seus discípulos ao ser preso e rendeu-se à morte. Da mesma forma também acontece em $O$ novo sistema:

Escudeiro-mor: Muito bem, senhores. Eis a minha resposta: a prática do Novo Sistema nasceu da necessidade, de contradiçóes sérias e profundas do Velho Sistema político, para as quais parecia năo haver saída. E continuo: a força do Novo Sistema está na consistência e na simplicidade com que resolve todas as dificuldades usando apenas (aponta os postes) umas poucas práticas, executadas de maneira muito convincente (HILST, 2008, p.361).

A repressăo é uma artimanha para a manutençâo do novo sistema. A referência é o aprisionamento do homem:

"[...] a pergunta que me faço e faço a todos é a seguinte: é lícito dar ao outro um tal nível de intensidade, vivendo todos nós nesse mundo dissociado, caótico, absurdo, esquizofrênico em que vivemos? Quem compreende esse mundo cindido nos leva inexoravelmente à decomposiçăo de nós mesmos, à degradaçăo de nós mesmos, à morte e ao esquecimento do que realmente somos ou poderíamos ter sido, forçosamente se vê levado, para sobreviver, a compactuar com o status quo" (HILST, 2013, p.59). 
Nos postes, estâo corpos expostos para impor o poder e lembrarem a populaçăo das novas regras. ${ }^{13}$ Ao final, o Menino se curva ao sistema assim como o Homem: este gesto simboliza a aceitaçăo do sistema. Se nâo é pelo amor, é pela dor (referência religiosa), ou pela vida: "Durante as exclamaçōes de He! Ha! o menino lentamente curva-se sobre si mesmo até ficar ajoelhado, curvado e imóvel. As exclamaçóes de He! Ha! Terminam com um Ha!" (HILST, 2008, p.361, grifo nosso). A violência é um dos elementos de metamorfose do homem, capaz de corromper seus valores, emudecer as opiniôes e redefinir as posiçóes contra ou a favor.

\section{CONCLUSÃO}

A ditadura militar brasileira, especialmente os anos de 1960, formam a base de análise deste artigo, mas nâo há como deixar de mencionar o pós-guerra, o pós-holocausto, as ditaduras na América Latina, pois tudo, certamente, influenciou o pensamento de Hilda Hilst. A escritora, por sua vez, tentou traduzir em palavras a sua percepção acerca desses eventos. As questóes religiosas e políticas manifestadas nos textos de Hilda Hilst simbolizam uma ferida exposta dos momentos em que os estados de exceçâo săo executados, independentes de quais estejam sendo referidos naquele momento. Sáo eles que nos levam a estar no limite, que pode ser entendido de diversas maneiras, seja no viés matemático, no sentido de extensăo ou, ainda, como retratamos nessa análise, no sentido figurado. Hilda Hilst provoca o leitor a (re) pensar sua existência e toda forma de repressấo que nos cerca, por isso utiliza uma linguagem expressiva na qual a interpretaçăo pode depender do contexto de cada indivíduo. Assim, quando dialogamos com o limite do ser humano, pensamos na representaçâo de um ser que ultrapassa a fronteira do suportável, chegando, entâo, a seu extremo:

Tenho muito medo, tenho pânico das situaçóes-limite. Acho que eu escrevo sobre elas para me exorcizar. A paixăo, a morte, o perguntar-se. Tenho muito medo de mim também, por isso escrevo. Escrever é ir em direçăo a muitas vidas e muitas mortes (HILST, 2013, p.151).

Hilda Hilst, em quase toda sua obra, trabalha com a limitaçăo do ser humano, com o aspecto metafísico da sobrevivência humana em diversos campos sociais. Em sua dramaturgia, podemos notar condiçóes de esperança, medo, fome e morte, palavras estas que representam o contexto histórico de sua escrita e evidenciam as facetas de um Brasil tâo atual, ao lidar com golpe de estado, militares no poder, a transformaçáo do ser humano, a ganância e as aparências.

Náo há como negar a existência da representaçăo da repressăo, uma vez que a própria autora afirma que fez uso de alegorias para "dar seu recado", porque sentia

13 Essa relaçâo espetacular é apontada por Foucault: "[...] a justiça só prendia uma porçâo irrisória de criminosos; ela se utilizava do fato para dizer: é preciso que a puniçáo seja espetacular para que os outros tenham medo. Portanto, poder violento e que devia, pela virtude de seu exemplo, assegurar as funçóes de continuidade" (FOUCAULT, 1979, p.217). Assim as relaçōes de humilhaçâo na presença de outros presos como fazem os SSs de As aves da noite ou matar o Verdugo e o Homem em praça pública, sâo elementos de repressăo, representaçōes de poder para gerar a obediência e o medo. 
medo de sofrer retaliaçăo física dos militares. A dramaturgia de Hilst é, sem dúvidas, sinônimo de resistência náo apenas pela forma como (re) apresenta o estado de exceçáo brasileiro, mas também por ter conseguido ser premiada com $O$ verdugo, que apresenta a violência e o poder como temas centrais do enredo, ainda diante do regime de ditadura militar. Buscamos demonstrar aqui a genialidade desta escritora capaz de escrever teatro, isto é, uma das artes mais perseguidas pelo regime militar no Brasil, e recontar a história náo pelo olhar do oprimido ou do opressor, mas através de uma alegoria que permeia a poesia, a história, a ficçâo, a resistência e sobretudo, a vulnerabilidade de ser humano. Sem dúvida, tratar de Hilda Hilst e de sua obra é um desafio, a sua complexidade faz jus à quantidade de referências que a autora possui em sua escrita. Suas concepçōes de mundo estăo ligadas ao que vivenciou e leu ao longo de sua trajetória, tanto que é difícil definir em que local sua dramaturgia se encontra: năo é religiosa, năo é engajada, năo é existencial, mas é tudo ao mesmo tempo, é hibrida no sentido mais amplo da palavra.

\section{REFERÊNCIAS}

ABREU, Caio Fernando. Sobre a Obsena Senhora D. Săo Paulo, 1982. Disponível em <http://www.angelfire.com/ri/casadosol/criticacfa.html> acesso em 30 de maio de 2016.

ARAÚJO, Laura Castro de. A dramaturgia de autoria feminina: 1990 a 2005. In: XII Seminário Nacional Mulher e Literatura e do III Seminário Internacional Mulher e Literatura - Gênero, Identidade e Hibridismo Cultural, do GT Mulher e Literatura da ANPOLL (Associaçăo Nacional de Pós-Graduaçăo em Letras e Linguística). Bahia, Ilhéus. Universidade Estadual de Santa Cruz. ANAIS. s.d, s.n. Disponível em <http://www.uesc. $\mathrm{br} /$ seminariomulher/anais/PDF/LAURA\%20CASTRO\%20DE\%20ARA\%C3\%9AJO.pdf> acesso em 04 de abril de 2017.

BOAL, Augusto. Teatro do oprimido e outras poéticas políticas. Rio de Janeiro: Editora Civilizaçāo Brasileira, 1991. 6. ed.

BOGART, Anne. A preparaçâo do diretor: sete ensaios sobre arte e teatro. Traduçăo Anna Vianna: revisăo de traduçăo Fernando Santos. Săo Paulo: WMF Martins Fontes, 2011.

DINIZ, Cristiano (org.). Fico Besta quando me entendem: entrevistas com Hilda Hilst Sáo Paulo: Globo, 2013.

FIGUEIREDO, César Alessandro. A ditadura militar no Brasil: memória e resistência da classe artística. Revista eletrônica de Ciência Política, vol.6, n.2, 2015. p. 7- 27.

FOUCAULT, Michel. Microfísica do poder. Traduçăo de Roberto Machado. Rio de Janeiro: Ediçăo Graal, 1979. 
HILST, Hilda, 1930-2004. Teatro completo/Hilda Hilst; posfácio Renata Pallottini. Săo Paulo: Globo, 2008.

HILST, Hilda. Fico besta quando me entendem: entrevistas com Hilda Hilst. Org: Cristiano Diniz. Săo Paulo: Globo, 2013.

MEDEIROS, Daniel. H. de. 1968: Esquina do Mundo. Săo Paulo: Editora Brasil, 1999. (Coleçăo De Olho na História).

OLIVEIRA, Leandro da Silva. Representaçôes do corpo na obra de Hilda Hilst. Campinas, SP: [s.n], 2013.

PALLOTINI, Renata. Do Teatro. In: HILST, Hilda. Teatro Completo. Săo Paulo: Globo, 2008.

SÍMBOLOS, Dicionário de. Triângulo. Disponível em: <https://www.dicionariodesimbolos.com.br/triangulo/>, acesso em 12 de julho de 2017.

VENTURA, Zuenir. 1968: O ano que năo terminou. Rio de Janeiro: Nova Fronteira, 1988.

VINCENZO, Elza Cunha de. Um teatro da mulher. Săo Paulo: Perspectiva, 1992. 